\title{
Os Papéis do Jornalismo em Desastres: Uma Análise com Base na Experiência dos Jornalistas
}

\author{
Juliana Frandalozo Alves dos Santos ${ }^{1}$, Ana Maria Bencciveni Franzoni ${ }^{2}$
}

\begin{abstract}
RESUMO
O Jornalismo desempenha papeis importantes na gestão de risco e desastre, mas pouco sabemos sobre seus limites, as dificuldades para exercê-los, o que é papel reconhecido, e o que é esperado, mas não está nas funções jornalísticas. Este artigo tem o objetivo de compreender o papel do Jornalismo em desastres, a partir da análise de conteúdo de 13 entrevistas qualitativas semiestruturadas feitas com jornalistas brasileiros com experiência em cobertura de desastres, e da revisão literária. Os resultados mostram que os papeis atribuídos ao Jornalismo que têm relação direta com os fundamentos da profissão não mudam, mas outros papeis surgem, ou ganham mais ênfase nos desastres e alguns, alternativos, acabam sendo exercidos pelos jornalistas em campo, mesmo sem ter preparo emocional, ou um treinamento específico para isso. Este estudo provê uma perspectiva reflexiva sobre as dificuldades enfrentadas pelos jornalistas durante a cobertura de desastres, relacionadas com os papeis autopercebidos, reconhecidos e alternativos, e busca reforçar a necessidade de compreensão da dimensão psicológica no trabalho em eventos extremos.
\end{abstract}

Palavras-chave: Jornalismo; desastre; cobertura jornalística; gestão de risco e desastre; fundamentos do Jornalismo

\footnotetext{
1 Mestre em Jornalismo, pela Universidade Federal de Santa Catarina. Doutoranda em Engenharia e Gestão do Conhecimento, pela Universidade Federal de Santa Catarina, Bolsista Capes/Proex de Doutorado, Dedicação exclusiva, Florianópolis, Santa Catarina, Brasil, ORCID: https://orcid.org/0000-0001-7128-1127, e-mail: jfrandalozo@gmail.com

2 Doutora em Geociências e Meio Ambiente, pela Universidade Estadual Paulista Júlio de Mesquita Filho/UNESP. Professora Titular do Programa de Pós-Graduação em Engenharia e Gestão do Conhecimento e do Departamento de Engenharia Civil da Universidade Federal de Santa Catarina, Florianópolis, Santa Catarina, Brasil, ORCID: https://orcid.org/0000-0002-8744-256X, e-mail: afranzoni@gmail.com
} 


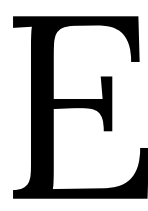

m um desastre ${ }^{3}$, informação se torna tão importante quanto água, comida, remédios e abrigo. Ela pode ser a única forma de prevenção de desastres financeiramente acessível aos mais vulneráveis, mas mesmo assim, ainda é muito negligenciada ${ }^{4}$. Na comunicação de desastres, os jornalistas desempenham um papel fundamental, fornecendo informações e avisos antes e durante esses eventos ${ }^{5}$ e contribuindo para trazer maior atenção a questões relacionadas às mudanças climáticas, como políticas que se concentram na adaptação e mitigação ${ }^{6}$, pois desastres trazem maior notoriedade para as notícias sobre mudanças climáticas ${ }^{7}$. Em um estudo sobre o surgimento do jornalismo climático nas Filipinas, uma das nações mais vulneráveis aos efeitos das mudanças climáticas, observou-se que depois de eventos climáticos extremos, particularmente o tufão Haiyan em 2013, os artigos de notícias sobre mudanças climáticas apresentaram um crescimento nos anos seguintes, sugerindo uma percepção maior dos profissionais sobre o assunto ${ }^{8}$.

Na cobertura de grandes desastres, a imprensa representa um meio confiável e verificável para enviar informação ${ }^{9}$ e também contribui, de forma consciente ou não, para mobilizar ações de resposta da sociedade, pela comoção pública e pela informação massiva, o que pressiona autoridades para a tomada de medidas de redução de riscos no pós-desastre. Práticas apropriadas no relato de desastres podem ter impactos significativos nos resultados para o gerenciamento de respostas e nas atitudes de prevenção a desastres ${ }^{10}$.

Os fundamentos do fazer jornalismo são os mesmos em coberturas de desastres ou de notícias ordinárias, como acidentes de trânsito e buracos de rua. São

\footnotetext{
3 Para sincronizar o conhecimento sobre desastres, adotamos os conceitos internacionais padronizados pela terminologia da Estratégia Internacional de Redução de Desastres da Organização das Nações Unidas (EIRD ONU): "desastre é uma séria interrupção no funcionamento de uma comunidade ou sociedade causando uma grande quantidade de mortes, bem como perdas e impactos materiais, econômicos e ambientais que excedem a capacidade da comunidade ou sociedade afetada de fazer frente à situação mediante o uso de seus próprios recursos".

UNISDR. Terminologia de reducción de riesgo de desastres, p. 13-14.

${ }^{4}$ IFRC, World Disasters Report 2005 (Geneve: IFRC, 2005).

5 Jacqui Ewart and Hamish McLean, "Best practice approaches for reporting disasters," Journalism (2019), Vol. 20 (12) $1573-1592$.

${ }^{6}$ Erin Friedman, Rebekah Breitze and William Solecki, "Communicating extreme event policy windows: Discourses on Hurricane Sandy and policy change in Boston and New York City," Environmental Science and Policy 100 (2019) 55-65.

7 Suzannah Evans Comfort, "From ignored to banner story: The role of natural disasters in influencing the newsworthiness of climate change in the Philippines," Journalism (2019), Vol. 20(12) 1630- 1647.

${ }^{8}$ Comfort. "From ignored to banner story"

$9 \mathrm{~J}$. Brian Houston et al., "Disaster journalism: fostering citizen and community disaster mitigation, preparedness, response, recovery, and resilience across the disaster cycle," Disasters, Volume 43, Issue3 (July, 2019) Pages 591-611.

10 Ewart and McLean, "Best practice".
} 
eles que garantem a qualidade de uma notícia ordinária e de uma extraordinária: a objetividade, enquanto compromisso com fatos reais e método de verificação; a concepção da verdade, com base na pluralidade e credibilidade de fontes; e a relevância dos fatos de maior interesse público ${ }^{11}$.

No entanto, há particularidades que devem ser consideradas, que levam em conta os papeis que o Jornalismo assume ao cobrir desastres. $\mathrm{Na}$ pandemia ${ }^{12}$ do coronavírus SARS-CoV-2, mais conhecido como COVID-19, dois papeis que se destacam fortemente na imprensa brasileira é a de checagem das informações, de forma independente do governo e o combate às fake news, que dominam as mídias sociais e representam um desafio também em outros paíse ${ }^{13}{ }^{14}$ 15, e influenciam, inclusive, tomadores de decisões, em nível governamental.

Qualquer que seja o modo de comunicação, o valor, a confiabilidade e a pontualidade das informações dependem da cooperação entre os órgãos que gerenciam a emergência e os jornalistas. Esse relacionamento é, por vezes, tenso ou impraticável em inúmeras situações de desastre e crise ${ }^{16}{ }^{17}$, o que acaba gerando desconfiança da população em relação ao poder público e à imprensa e uma sensação de "cada um por si", que prejudica as ações de resposta.

Nenhum desastre é igual ao outro ${ }^{18}$ e, se mesmo equipes de resposta se deparam com situações inusitadas e comoventes, é evidente que os profissionais de

\footnotetext{
11 Juliana F. A. Santos, "Do desastre para o risco: qualidade na cobertura em revistas semanais de informação." (Mestrado, Universidade Federal de Santa Catarina, 2014).

12 Pandemia é, de acordo com a Classificação e Codificação Brasileira de Desastres (Cobrade), um desastre natural, grupo biológico, subgrupo epidemia, tipo doenças infecciosas virais, definição: aumento brusco, significativo e transitório da ocorrência de doenças infecciosas geradas por vírus (1.5.1.1.0). Brasil. Ministério da Integração Nacional. Secretaria Nacional de Defesa Civil. Centro Nacional de Gerenciamento de Riscos e Desastres. "Anuário brasileiro de desastres naturais: 2012" (Centro Nacional de Gerenciamento de Riscos e Desastres. - Brasília: CENAD, 2012).

13 Jinling Hua and Rajib Shaw, "Corona Virus (COVID-19) "Infodemic" and Emerging Issues through a Data Lens: The Case of China", Int. J. Environ. Res. Public Health (2020), 17, 2309

14 Viet-Phuong La et al., "Policy Response, Social Media and Science Journalism for the Sustainability of the Public Health System Amid the COVID-19 Outbreak: The Vietnam Lessons," Sustainability (2020), 12, 2931.

15 Cristina Pulido et al., "COVID-19 infodemic: More retweets for science-based information on coronavirus than for false information," International Sociology (2020), 1-16.

16 Joseph Campbell, "Getting It Wrong: Ten of the Greatest Misreported Stories in American Journalism," (Berkeley, CA, Estados Unidos: University of California Press, 2010).

17 Hamish McLean and Mary R Power, "When minutes count: Tension and trust in the relationship between emergency managers and the media," Journalism, Vol. 15(3) 307-325 (2013).

18 Os desastres são classificados de acordo com sua causa e evolução. No Brasil, adotamos a Classificação e Codificação Brasileira de Desastres, Cobrade, que divide os desastres em duas categorias principais: naturais e tecnológicos. A categoria desastres naturais divide-se em cinco grupos, treze subgrupos, vinte e quatro tipos e vinte e três subtipos. Os desastres tecnológicos se dividem em cinco grupos, quinze subgrupos e onze tipos.
} 
imprensa, a maioria sem nenhum treinamento específico ${ }^{19}$, também vão encontrar dificuldades $^{20}$. E essas dificuldades afetam a forma como o próprio jornalista percebe seu papel diante do desastre, a utilidade do Jornalismo em um momento tão dramático ${ }^{21}$ e em sua saúde mental, que muitas vezes é negligenciada'22 232425262728 .

Este artigo aborda esses fatores que dificultam a cobertura, relacionados aos papeis autopercebidos pelos jornalistas, papeis reconhecidos pela sociedade e também papeis alternativos, abraçados pelos profissionais de forma improvisada.

\section{METODOLOGIA}

Este é um estudo qualitativo, desenvolvido com o objetivo de compreender o papel do Jornalismo em diferentes desastres e visando responder a duas questões de pesquisa: (1) o que as pesquisas relacionadas a Jornalismo e desastres têm a contribuir com a problematização dos diferentes papeis executados pelos jornalistas em um desastre?; (2) quais reflexões os jornalistas trazem, relacionadas ao papel do Jornalismo na cobertura de desastres?

Para responder a estes questionamentos, foi feita uma revisão de literatura atualizada, reunindo artigos publicado na base de dados Scopus entre 2010 e 2020. Usamos também dados coletados para a pesquisa "Do desastre para o risco: qualidade

\footnotetext{
Brasil. Ministério da Integração Nacional. Secretaria Nacional de Defesa Civil. Centro Nacional de Gerenciamento de Riscos e Desastres. "Anuário brasileiro de desastres naturais: 2012" (Centro Nacional de Gerenciamento de Riscos e Desastres. - Brasília: CENAD, 2012).

19 Santos, "Do desastre para o risco".

20 Santos, "Do desastre para o risco".

21 Desiree Hill, Catherine A. Luther, and Phyllis Slocum, "Preparing Future Journalists for Trauma on the Job," Journalism \& Mass Communication Educator (2020), Vol. 75(1) 64-68.

22 Patrice A. Keats and Marla J. Buchanan, "Covering Trauma in Canadian Journalism: Exploring the Challenges," Traumatology 19(3) 210-222, (2012).

${ }^{23}$ Gretchen Dworznik-Hoak, "Weathering the Storm: Occupational Stress in Journalists Who Covered Hurricane Harvey," Journalism Studies, 21:1, 88-106 (2020).

24 Natalee Seely, "Fostering Trauma Literacy: From the Classroom to the Newsroom". Journalism \& Mass Communication Educator, Vol 75, Issue 1, (2020).

${ }^{25}$ Houston et al., "Disaster journalism".

${ }^{26}$ Melanie Verhovnik, "Trauma journalism and disaster resilience. German journalists' coping strategies when reporting about crime, violence, accidents, crises and natural disasters," Studies in Communication Sciences 17.2 (2017), pp. 209-220.

${ }_{27}$ Hill, Luther and Slocum, "Preparing".

28 Deborah Potter and Sherry Ricchiardi, Disaster and Crisis Coverage. International Center for Journalists, 2009.
} 
na cobertura em revistas semanais de informação"29: entrevistas semiestruturadas

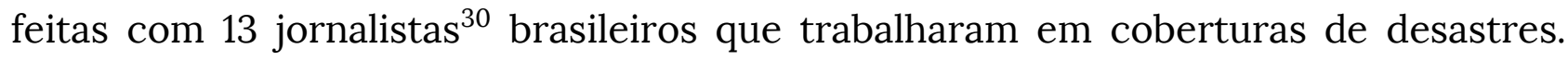
Essas entrevistas foram realizadas entre abril e maio de 2013, logo após uma sequência de megadesastres que atingiu o país ${ }^{31}$.

A importância que o Jornalismo adquire em momentos de desastre justifica uma pesquisa no assunto para compreender os papeis que os jornalistas percebem ter, os que assumem de improviso, como papeis alternativos, e os que são legados a eles e às empresas jornalísticas.

Para avaliar a quantidade de publicações sobre o tema "Jornalismo e desastres", foi feita, inicialmente, uma busca na base de dados Scopus, com as palavras-chave "journalism AND disaster", filtrada pelos parâmetros: tipo de publicação (article; review); estágio de publicação (final); language (english; spanish). Resultou em 115 artigos e 9 reviews. Para decidir sobre os parâmetros de seleção, filtramos a busca para abranger artigos publicados nos últimos dez anos, de 2010 a 2020, e obtivemos 98 artigos. Para sincronizar os artigos de revisão com o objetivo de pesquisa, inserimos mais uma palavra à busca dentro dos resultados, "practice", refinando-a para 65 publicações.

Com esta filtragem, foi feita uma seleção qualitativa das publicações, com base nos seguintes critérios: estão excluídos os artigos que tratam de desastres de forma superficial, não como ciência; estão incluídos os artigos cujo resumo contribua para as questões de pesquisa. Junto à revisão literária foram acrescentadas publicações consideradas relevantes para o estudo, que não figuraram nas buscas na base de dados.

Os dados obtidos nas entrevistas e na revisão literária passam por análise de conteúdo. A partir da análise, os resultados foram sintetizados em três tópicos principais: (1) características do Jornalismo em desastres; (2) papeis reconhecidos e

\footnotetext{
29 Santos, "Do desastre para o risco".

30 A seguir, a relação dos 13 jornalistas entrevistados e o cargo que ocupava nas coberturas que geraram os relatos: Igor Paulin, repórter; Liliani Bento, repórter freelance; Solange Azevedo, repórter; Giselle Zambiazzi, repórter freelance; Alexandre Mansur, editor executivo; Celso Masson, editor executivo; Leopoldo Mateus, repórter; Letícia Sorg, repórter; Aline Ribeiro, repórter; Rafael Pereira, repórter; Daniela Mendes, editora-executiva; Luiz Fernando Sá, diretor editorial adjunto; Wilson Aquino, repórter.

31 Enxurradas em Santa Catarina, em 2008; a queda do Airbus A330, voo Air France 447, no oceano Atlântico, em 2009; deslizamentos no Morro do Bumba, em Niterói e Angra dos Reis, em 2010; enxurrada na Região Serrana do Rio de Janeiro, em 2011; desabamento de prédios em 2012, no Rio de Janeiro; incêndio na Boate Kiss, em 2013.
} 
papeis alternativos; (3) dificuldades na cobertura de desastres. Um quarto tópico foi acrescentado para abordas um aspecto específico apontado na literatura, que contribui para a discussão: desenvolvendo resiliência diante de desastres e resiliência psicológica.

\section{RESULTADOS}

CARACTERÍSTICAS DO JORNALISMO EM DESASTRES

A cobertura de desastres é uma das mais complexas, pois envolve dificuldades, por vezes, imprevisíveis, de acordo com a evolução única de cada desastre. As dificuldades mais óbvias são as logísticas, como problemas de transporte e locomoção, por causa de vias interditadas e destruídas, falta de energia elétrica, queda de torres de celular, dificuldade em obter internet ou qualquer outra forma de comunicação e desabastecimento ${ }^{32} 33$. O regime de trabalho se torna cansativo, física e psicologicamente, pois há o estresse emocional em lidar com pessoas em sofrimento ${ }^{34} 3536$ e o desafio de lidar com uma quantidade enorme de informações em pouco espaço de tempo e condições adversas.

Essas dificuldades surgem para todos os veículos de imprensa, mas cada tipo possui uma estrutura específica e uma função diferente em um desastre ${ }^{37}$.

Mclean e Power ${ }^{38}$ afirmam que apesar da proliferação de redes de mídia social, a mídia tradicional é uma ferramenta vital no gerenciamento de emergências, devido

\footnotetext{
32 Yadira Nieves-Pizarro, Bruno Takahashi and Manuel Chavez, "When Everything Else Fails: Radio Journalism During Hurricane Maria in Puerto Rico." Journalism Practice (2019), Vol. 13, n. 7, 799-816.

33 Sibila Camps, Periodismo sobre catástrofes: cómo cubrir catástrofes, emergencias y accidentes en medios de transporte (Buenos Aires: Paulinas, 1999).

34 Natalee Seely, "Fostering".

35 Santos, "Do desastre para o risco".

${ }^{36}$ Camps, Periodismo sobre catástrofes.

${ }^{37}$ Camps, Periodismo sobre catástrofes.
} 
ao alcance do público. No entanto, pesquisas apontam que justamente por conta da enorme proliferação de informações nas mídias sociais, é que a imprensa tradicional desempenha um papel muito importante na gestão de riscos e desastres ${ }^{39}{ }^{40}$, pois o lado negativo da rápida resposta da mídia social é um forte surgimento de notícias falsas ${ }^{41}$.

Dos veículos tradicionais, a televisão ainda ocupa um papel privilegiado na mobilização da opinião pública. Durante o terremoto de 2010, no Chile, 56\% da audiência nacional declarou ter visto mais televisão do que o habitual, os chilenos se voltaram para canais de televisão abertos para descobrir os detalhes do que estava acontecendo $^{42}$. Ela ultrapassa os limites da localidade e dificilmente é afetada de modo a não conseguir transmitir. Consegue enviar equipes e transmitir o material rapidamente, mobilizando ajuda e influenciando autoridades na resposta rápida. A força da imagem é sua principal marca. Difícil quem não se emociona ao assistir as imagens de um desastre, os relatos de sobreviventes, os resgates difíceis. A TV nacionaliza e internacionaliza o desastre e a cobertura ao vivo é sua principal força.

No entanto, essa força pode também virar uma armadilha para os repórteres.

Na manhã de 14 de janeiro de 2011, Nova Friburgo, uma das cidades mais afetadas pela enxurrada e deslizamentos de terra que devastaram a região serrana do Rio de Janeiro apenas dois dias antes, viveu um momento de pânico. Informações desencontradas diziam que a represa havia se rompido e que a cidade seria inundada pelo rio que atravessa a região central. Todos na cidade começaram a correr para regiões mais altas. Entre as pessoas estavam três equipes de TV, duas da Rede Globo e uma da Rede Record que mostraram reações distintas. Uma das equipes da rede Globo, do repórter Guilherme Portanova, estava descansando quando soube do fato e correu para se salvar, sem registrar imagens. Ele apenas fez o relato na edição ao vivo do Jornal Hoje, contando o que havia testemunhado e o que tinha apurado de informações sobre o caso. A outra equipe, que estava de serviço no momento, com a

\footnotetext{
38 McLean and Power, "When minutes".

39 Hua and Shaw, "Corona Virus (COVID-19)"

40 Pulido, Cristina M. et al., "COVID-19 infodemic"

41 La et al., "Policy".

42 D. Grassau et al., "Perfiles y roles de los conductores de TV en momentos de desastres: propuesta conceptual a partir del caso del terremoto del 27F en Chile," Revista de Comunicación, (2019), vol.18, n. 2.
} 
repórter Flávia Jannuzzi, ficou no local e fez imagens na rua próxima ao rio, entrevistando pessoas chorando e correndo, dizendo para a repórter correr também. Jannuzzi não aparece nas imagens, apenas sua voz fazendo as perguntas ${ }^{43}$.

A equipe da TV Record também fez um relato com a câmera em movimento, enquanto a repórter Vivian Carvalho corria pelas ruas entrevistando pessoas em pânico. A certa altura, a repórter chora e diz para a câmera: "a gente fica emocionado, é uma cidade destruída, as pessoas não tem mais casa, não tem mais vida [...] a situação é de pânico e medo também"44.

Pouco depois, foi constatado que não havia rompimento de represa. Mesmo autoridades e a própria Defesa Civil levaram um tempo para atinar que não havia represa na cidade e, portanto, não era possível que ela se rompesse. Era uma notícia falsa que se espalhou rapidamente na cidade abalada pelo desastre. No fim da manhã, já tinham conseguido controlar o pânico.

Analisar a atuação dos três repórteres no falso boato nos permite algumas reflexões sobre papeis no Jornalismo.

Primeiro: o repórter é testemunha ocular dos fatos ${ }^{4546}$, mas muitas vezes o fato é apenas o relato de pessoas e a verificação imediata não é possível. A fonte de verificação mais confiável naquele momento era o coordenador da Defesa Civil local, mas até ele acreditou no boato, em um primeiro momento. A pressão do tempo não pode ser inimiga da verificabilidade dos fatos. Por isso, a transparência na apuração é um elemento importante, ou seja, deixar claro o que é relato e o que é fato, o que se sabe e o que não se sabe sobre aquele fato.

Segundo: mesmo se houvesse desconfiança do fato, o primeiro instinto do repórter ou de qualquer pessoa deve ser garantir sua segurança ${ }^{47}$. A atuação tanto da equipe que estava descansando, quanto das duas equipes que estavam na rua

\footnotetext{
43 Rede Globo de Televisão. Jornal Hoje. "Moradores correm pelas ruas com medo de nova inundação." Nova Friburgo, RJ. Veiculado em 14 jan. 2011.

44 Rede Record de Televisão. Jornal da Record, "Boato de rompimento de represa gera pânico e tensão a Nova Friburgo." Nova Friburgo, RJ. Veiculado em 14 jan. 2011.

${ }^{45}$ Houston et al., "Disaster journalism".

46 River J. Smith, Susan Drevo and Elana Newman, "Covering traumatic news stories: Factors associated with posttraumatic stress disorder among journalists," Stress and Health (2017), 1-9.

47 Potter and Ricchiardi, "Disaster", p. 34.
} 
entrevistando pessoas, mostra sua preocupação com a segurança. Nos vídeos fica claro que as equipes que estavam na rua decidiram parar de gravar para correr.

Terceiro: vimos duas abordagens diferentes das repórteres na rua, a repórter em pânico, sensacionalizando o fato, e a repórter que deixa as imagens e os relatos dos entrevistados falarem por si. Ambas as matérias são comoventes, pois o fato, em si, já é dramático. Em momentos como esse, é aconselhado manter a calma, escolher as palavras com muito cuidado para evitar piorar a situação ou causar mais estresse ou pânico e cuidado com o tom e o volume da voz ${ }^{48} 49$. "Expressar suas emoções pessoais no ar é uma coisa (...), mas os jornalistas devem ter cuidado para não expressar pânico, o que pode prejudicar sua credibilidade ao cobrir um desastre" ${ }^{50}$.

Já o rádio é um veículo essencial para emergências ${ }^{51}$. Por ser da mídia local, seus profissionais conhecem toda a região e podem se locomover facilmente nas áreas afetadas, por caminhos alternativos, já que é muito comum haver vias interrompidas em desastres provocados por chuvas, os mais comuns no Brasil. A transmissão pode ser feita com geradores, sem necessidade de muita energia e os aparelhos dos ouvintes são pequenos, leves e abastecidos com pilhas e baterias ${ }^{52}$. Por esse motivo um rádio portátil faz parte do material de emergência recomendado pela Defesa $\mathrm{Civil}^{53}$. O rádio portátil é, muitas vezes, a única forma de obter informações em uma área atingida ${ }^{54}$, como foi em Florianópolis, Santa Catarina, entre os dias 29 e 31 de outubro de 2003, quando um incêndio danificou os cabos de transmissão de energia elétrica em uma das pontes que liga a ilha ao continente. Sem outra forma de transmissão de energia, os mais de 400 mil moradores da ilha foram afetados e a mídia local ficou parcialmente impotente. O medo do que podia acontecer a uma cidade mergulhada na escuridão fez com que as vias de saída, também concentradas

\footnotetext{
48 Potter and Ricchiardi, "Disaster", p. 30.

49 D. Grassau et al., "Perfiles y roles de los conductores de TV en momentos de desastres: propuesta conceptual a partir del cas 0 del terremoto del 27F en Chile" Revista de Comunicación, 2019, vol.18, n. 2.

50 Potter and Ricchiardi, "Disaster", p. 30.

51 McLean and Power, "When minutes".

52 McLean and Power, "When minutes".

53 Defesa Civil é o "conjunto de ações preventivas, de socorro, assistenciais, reabilitadoras e reconstrutivas destinadas a evitar ou minimizar desastres, preservar o moral da população e restabelecer a normalidade social. A finalidade da defesa civil é promo ver a segurança global da população, em circunstâncias de desastres naturais, antropogênicos e mistos". Antônio Luiz Coimbra de Castro. Manual de Planejamento em Defesa Civil - 4 volumes. (Brasília: Ministério da Integração Nacional. Secretaria de Defesa Civil, 1999), p. 10.

54 McLean and Power, "When minutes".
} 
em uma ponte, ficassem congestionadas e coube ao rádio, mesmo com dificuldades de manter a transmissão, o papel de auxiliar na resposta e tranquilizar a população. As rádios locais, especialmente as AM Rádio Guararema e a CBN Diário ${ }^{55}$, que tinham geradores capazes de manter as transmissões, mobilizaram suas equipes por 55 horas ininterruptas, a fim de manter a população informada até o reestabelecimento da energia em toda a cidade.

Se a TV mobiliza e emociona por meio das imagens e o rádio auxilia no atendimento imediato à emergência, cabe aos veículos impressos diários e suas versões online fazerem o registro que vai perdurar para a posteridade, fornecer informações mais detalhadas, com contexto e profundidade e publicar editoriais que, muitas vezes, marcam a posição do veículo diante do cenário e estimulam políticas públicas. Suas notícias alimentam as mídias sociais, mobilizam ajuda e contribuem para formar um histórico do desastre. Não é à toa que os bancos de dados do Emergency Disasters Data Base (EM-DAT), mantido pelo Centro para a Pesquisa sobre a Epidemiologia de Desastres (CRED), na Bélgica, e o Sistema Integrado de Informações sobre Desastres (S2ID) ${ }^{56}$, operado pela Secretaria Nacional de Proteção e Defesa Civil do Brasil, utilizam jornais diários como uma das fontes de pesquisa para levantar históricos de desastres. Usar o texto da mídia como fonte importante de dados é uma tendência destes estudos ${ }^{57}$ e também de processos judiciais.

\section{PAPÉIS RECONHECIDOS E PAPÉIS ALTERNATIVOS}

Os papéis mais comuns do Jornalismo em desastres são divulgar avisos e alertas à comunidade, investigar o evento, enviar jornalistas para o local, fornecer informações básicas e verificá-las, corrigir rumores e trabalhar para reunir material

\footnotetext{
55 Carol Denardi and Ricardo Medeiros, "CBN Diário: uma luz no apagão" (Florianópolis: Insular, 2007)

56 Banco de Dados S2ID. Banco de Dados de Registros de Desastres. Ministério da Integração Nacional. Secretaria Nacional de Defesa Civil. Universidade Federal de Santa Catarina. Centro Universitário de Estudos e Pesquisas sobre Desastres. "Sistema Integrado de Informações sobre Desastres."

57 Friedman, Breitze and Solecki, "Communicating".
} 
adicional, que permita o aprofundamento e as explicações que a população necessita ${ }^{58}$ 59 .

O registro histórico dos fatos a partir dos produtos jornalísticos é um assunto pouco debatido. Este é um papel negligenciado por grande parte das empresas de mídia, pois o Jornalismo produz material para consumo imediato. Muitos jornais não têm procedimentos de armazenamento, catalogação e disponibilização de suas edições e quando as empresas fecham, esse material de valor histórico se perde. Algumas organizações com bibliotecas abraçam a tarefa de arquivar e digitalizar edições dos principais veículos de mídia, mas nem sempre essa catalogação é abrangente ou permanente. Mesmo assim, o registro da memória social que o Jornalismo produz é material de análises históricas, antropológicas, sociológicas e também de outras ciências, que produzem novos conhecimentos, opiniões, dúvidas, debates, novos fatos e versões ${ }^{60}$.

Apesar da tendência dos jornalistas em assumirem papeis alternativos ${ }^{61}$, é necessário reconhecer que muitos deles não estão preparados para isso ${ }^{62}$. Reconhecer os papeis não assumidos nos apresenta um campo de estudos pouco explorado. O papel de socorrista, por exemplo, foi analisado por alguns pesquisadores ${ }^{63} 64$, já que jornalistas estão entre os primeiros a chegar às áreas afetadas durante desastres naturais e exercem funções essenciais ${ }^{65}$. Durante a resposta ao furacão Maria, em Porto Rico, os jornalistas receberam o status de socorristas, equivalente a paramédicos, bombeiros e policiais, para que pudessem ignorar o toque de recolher ao pôr do sol, ter acesso a recursos escassos, como a gasolina, que lhes permitiriam desempenhar a função vital de comunicação, muito necessária em um contexto de compartilhamento limitado de informações precisas ${ }^{66}$. Esse papel teve resultados adicionais: alguns jornalistas relataram se sentir culpados por terem benefícios que o

\footnotetext{
58 Houston et al., "Disaster journalism".

59 McLean and Power, "When minutes".

60 Francisco José Castilhos Karam, "A ética jornalística e o interesse público". (São Paulo: Summus, 2004), p. 31.

61 Edson C. Tandoc Jr. and Bruno Takahashi, "Journalists are humans, too: A phenomenology of covering the strongest storm on

Earth". Journalism 1- 7, 2016.

62 Hill, Luther and Slocum, "Preparing".

63 Tandoc Jr. and Takahashi, "Journalists".

64 Nieves-Pizarro, Takahashi and Chavez, "When".

65 Tandoc Jr. and Takahashi, "Journalists".

66 Nieves-Pizarro, Takahashi and Chavez, "When".
} 
restante da população não tinha e abriram mão de usufruir deles. Outros se sentiram na responsabilidade de ajudar, enchendo o carro de comida e coisas para distribuir aos afetados, pois consideravam falta de empatia e sensibilidade chegar nos locais destruídos apenas com suas ferramentas de trabalho ${ }^{67}$. Mas também é importante registrar que quatro jornalistas de rádio morreram enquanto trabalhavam na cobertura do furacão ${ }^{68}$. Não há como fazer uma correlação entre o papel alternativo e as fatalidades, mas isso mostra a exposição ao risco, para o qual nem sempre os profissionais estão preparados. Um dos entrevistados da pesquisa, ressalta esse risco:

A tragédia em Teresópolis se deu na periferia, onde o povo (ricos e pobres) construiu à beira dos rios e nos morros. Como os maiores deslizamentos transformaram bairros inteiros em locais de difícil acesso [...] tivemos que caminhar cerca de duas horas até o bairro de Campo Grande, um dos mais destruídos. O caminho era complicado: pedras gigantescas, muita lama e um cenário de destruição que impressionava (e assustava). O repórter tem que tomar cuidado para não virar vítima também. (Wilson Aquino, repórter)

Os profissionais de rádio podem operar deslocados do estúdio com pouco equipamento, e passar informações valiosas para os ouvintes afetados, mobilizar ajuda para áreas isoladas e reconectar famílias que se perderam ${ }^{69}$. Aliadas à Defesa Civil, as rádios têm o potencial de fazer chegar as informações certas ao público e aos gestores do desastre, como relata o jornalista Igor Paulin, um dos entrevistados da nossa pesquisa. Ele estava no Chile, cobrindo o terremoto seguido de tsunami, que devastou a região de Concepción, em $2010,{ }^{70}$ e acompanhou repórteres da rádio Concepción, que circulavam de carro pelos bairros e municípios da região:

Eram os únicos com autonomia e respaldo para circular entre as áreas dominadas pelas milícias, bandidos e exército. Eles anotavam pedidos de mantimentos, recados para desaparecidos e encaminhavam doações. A rádio suspendera sua programação musical e transmitia ininterruptamente os recados anotados pelas equipes e os repetia quantas vezes fosse necessário ao longo do dia. Era comum ouvir coisas do tipo: "Fulano de tal, seus pais avisam

\footnotetext{
${ }^{67}$ Nieves-Pizarro, Takahashi and Chavez, "When".

68 Tandoc Jr. and Takahashi, "Journalists".

69 Zimmermann, Arnaldo. "A Participação do público na cobertura radiofônica do desastre de 2008 em Blumenau." Mestrado, Universidade Federal de Santa Catarina, 2012.

70 A cidade de Concepción, a 400 quilômetros ao sul de Santiago, no Chile, foi atingida por um terremoto de 8,8 graus na escala Richter seguido de tsunami em 27 de fevereiro de 2010.
} 
que estão bem e estão abrigados na casa da tia. Pedem que você os procure por lá", "General Fulano, o bairro x sofre com saques. Duas crianças estão perdidas por lá", "Ciclana, seu filho nos ligou para dizer que está bem e está em tal abrigo" e "Faltam água, comida, roupas e cobertor em diversos pontos da cidade. A rádio recebe doações e as distribui, quem puder nos ajude". Por toda a cidade, as pessoas se reuniam em torno de radinhos para ouvir as notícias. Entre os principais pedidos de doações estavam pilhas. Não havia eletricidade e todos temiam ficar ainda mais no escuro sem ouvir a Conce. Os carros rodavam com o combustível que era doado até pelos saqueadores. (Igor Paulin, repórter)

Os radialistas estavam cumprindo o papel fundamental do Jornalismo, de informar, verificar informações e se colocar ao lado da comunidade. Mas vemos no relato os papeis alternativos, assumidos na necessidade e no improviso. Definimos como improviso, pois não há escola ou treinamento para ensinar aos jornalistas como proceder em momentos como esses ${ }^{71}$. Eles cumprem esses papeis por instinto.

No desastre, vários papeis alternativos surgem: fazer a ponte entre a ajuda humanitária e a comunidade; passar tranquilidade e ordem diante de uma catástrofe, em um lugar onde o poder público falta ${ }^{72}$. São papeis que não estão na descrição das funções fundamentais do jornalista e também não figuram nos planos de contingência para jornalistas $^{73}$. O ideal, em momentos de desastre, é que o poder público lidere a resposta e facilite a atuação dos serviços essenciais, como os órgãos de emergência, de infraestrutura, de segurança, saúde e de imprensa. No entanto, crises políticas, envolvendo corrupção e descaso das autoridades em meio a desastres ocorrem com certa frequência ${ }^{74}$ e prejudicam a assistência aos atingidos e o trabalho dos órgãos de emergência e serviços essenciais, como a imprensa.

Se os papeis alternativos exigem muito dos jornalistas em situações extremas, até mesmo para cumprir papeis fundamentais e levar informação de qualidade, os veículos impressos precisam improvisar, quando afetados pelo desastre. Durante a inundação provocada pelo rompimento dos diques após a passagem do furacão

\footnotetext{
71 Hill, Luther and Slocum, "Preparing".

72 Nieves-Pizarro, Takahashi and Chavez, "When".

73 "O planejamento de contingência tem por objetivo prever as medidas de resposta aos desastres, que devem ser desencadeados com a finalidade de reduzir os danos humanos, materiais e ambientais e os prejuízos econômicos e sociais". Antônio Luiz Coimbra de Castro. Manual de Planejamento em Defesa Civil - 4 volumes. (Brasília: Ministério da Integração Nacional. Secretaria de Defesa Civil, 1999), p. 22. A Defesa Civil estimula cada organização a desenvolver seu próprio plano, para não agir no improviso em um evento extremo.

74 Campbell, "Getting".
} 
Katrina, em 2005, nos EUA, o jornal local Times-Picayune teve a gráfica e a redação destruídas pelas águas. As edições do jornal foram impressas em uma universidade parceira e distribuídas gratuitamente pela região afetada, nas zonas habitáveis da cidade e nos abrigos onde se encontravam os desalojados de New Orleans ${ }^{75}$.

Com a ausência da resposta ao desastre por parte das autoridades, os jornalistas locais de New Orleans também assumiram papeis de improviso. Repórteres e fotógrafos trabalharam incansavelmente assumindo grandes riscos, dormindo pouco, se alimentando mal e enfrentando condições caóticas, para fazer as informações corretas chegarem às pessoas, tanto as que haviam permanecido na cidade, após a evacuação, quanto as que acompanhavam de longe as cinco semanas em que a cidade ficou debaixo d'água ${ }^{76}$ e questionar o governo sobre a demora na ajuda aos desabrigados e à cidade ${ }^{77}$. Uma das entrevistas aponta o papel de mobilizar a opinião pública como um dos mais importantes:

Percebi o quanto a nossa profissão é importante antes, durante e depois de um desastre, para prevenir, para ajudar na hora da necessidade e para levantar as discussões depois no trabalho de conscientização e prevenção para que não se repita. Veja o resultado, por exemplo, do que aconteceu na Boate Kiss no Rio Grande do Sul. Uma mobilização em todo o país para que a legislação se cumpra, coisa que antes todos fechavam os olhos. Depois da tragédia, a imprensa foi pra rua falar das condições das casas noturnas no Brasil inteiro. Cobrar. Divulgar. (Giselle Zambiazzi, repórter freelance)

As tarefas mais comuns do Jornalismo em desastres são fornecer avisos e alertas à comunidade, investigar o evento, enviar jornalistas para o local, fornecer informações básicas, verificar informações, corrigir rumores ou informações incorretas e trabalhar para reunir material adicional ${ }^{78}$. Mas percebemos que é muito comum que os jornalistas assumam papeis alternativos em desastres. E isso ocorre, principalmente devido à desorganização das ações de resposta que devem ser

\footnotetext{
75 Lisa Guernsey, "Hurricane Forces New Orleans Newspaper to Face a Daunting Set of Obstacles". The New York Times, September 5, 2005.

${ }^{76}$ Kathleen Tierney, Christine Bevc and Erica Kuligowski, "Metaphors matter: disaster myths, media frames, and their consequences in hurricane Katrina". The ANNALS of the American Academy of Political and Social Science. vol. 604 no. 1. Mar. 2006.

77 Campbell, "Getting".

78 Houston et al., "Disaster journalism".
} 
coordenadas pelo governo. Essa extrapolação dos papeis da imprensa podem representar um risco a mais para os profissionais em campo.

O quadro a seguir sintetiza as discussões dos entrevistados sobre os papeis do Jornalismo percebidos na cobertura de riscos e desastres e os papeis atribuídos e alternativos, encontrados na literatura.

Quadro 1 - Papéis do Jornalismo percebidos pelos entrevistados e alternativos, relatados na literatura.

\begin{tabular}{|c|c|}
\hline Papéis percebidos & Papéis atribuídos e alte \\
\hline $\begin{array}{l}\text { Informar, reportar a tragédia, divulgar, } \\
\text { relatar, fornecer informações verídicas } \\
\text { e verificáveis }\end{array}$ & $\begin{array}{l}\text { Funcionar como um mecanismo de } \\
\text { defesa, mantendo a comunidade unida } \\
\text { em uma crise }^{79}\end{array}$ \\
\hline $\begin{array}{l}\text { Organizar a informação em meio ao } \\
\text { caos de boatos e inverdades }\end{array}$ & $\begin{array}{l}\text { Fornecer diretamente suprimentos e } \\
\text { outras assistências à população } 8081\end{array}$ \\
\hline $\begin{array}{l}\text { Ouvir especialistas e técnicos, trazer } \\
\text { explicações claras e objetivas }\end{array}$ & $\begin{array}{l}\text { Tranquilizar a população, na ausência } \\
\text { do poder público }\end{array}$ \\
\hline Levantar discussões, conscientizar & histórico do \\
\hline $\begin{array}{l}\text { Promover o diálogo entre os atingidos } \\
\text { e os não-atingidos. Cultivar a } \\
\text { proximidade com a população }\end{array}$ & $\begin{array}{l}\text { Mobilizar ajuda para áreas isoladas e } \\
\text { reconectar famílias que se perderam }{ }^{84}\end{array}$ \\
\hline $\begin{array}{l}\text { Ampliar a cobertura de questões } \\
\text { ambientais }\end{array}$ & Socorrista 8586 \\
\hline $\begin{array}{l}\text { Fiscalizar, denunciar o descaso, } \\
\text { irregularidades, como o mau emprego }\end{array}$ & $\begin{array}{l}\text { Desenvolver conteúdo que promova a } \\
\text { mitigação e preparação para desastres, }\end{array}$ \\
\hline
\end{tabular}

\footnotetext{
79 Marla Perez-Lugo, "Media uses in disaster situations: a new focus on the impact phase". Sociological Inquiry, Volume 74, Issue 2, pages 210-225, (May 2004), p. 212.

80 Tandoc Jr. and Takahashi, "Journalists".

${ }^{81}$ Nieves-Pizarro, Takahashi and Chavez, "When".

82 Nieves-Pizarro, Takahashi and Chavez, "When".

83 Francisco José Castilhos Karam. "A ética jornalística e o interesse público". (São Paulo: Summus, 2004), p. 31.

84 Arnaldo Zimmermann, "A Participação do público na cobertura radiofônica do desastre de 2008 em Blumenau." Mestrado, Universidade Federal de Santa Catarina, 2012.

85 Tandoc Jr. and Takahashi, "Journalists".

86 Nieves-Pizarro, Takahashi and Chavez, "When".
} 


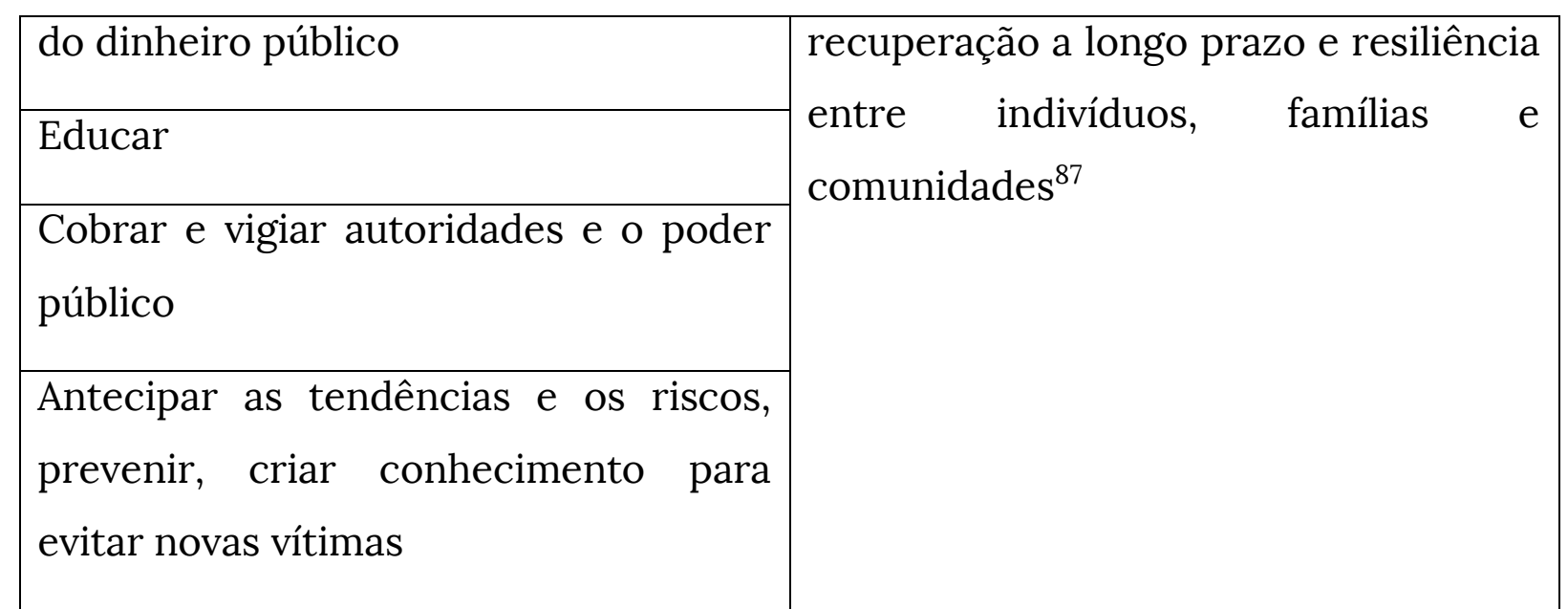

Fonte: Elaborado pelas autoras, 2020.

No quadro, o papel de educar foi citado por um dos jornalistas entrevistados, mas abre uma discussão que precisa ser debatida. Jornalistas não são treinados para educar, mas quando consideramos que educação é fruto de qualquer interação que promova aprendizado, o Jornalismo ganha um papel educador ${ }^{88}$.

A cobertura do risco também se destacou entre os entrevistados, que reconheceram a necessidade de aproximar as vulnerabilidades sociais da população com a questão dos desastres para trabalhar a questão do risco. O lado humano do desastre foi o que gerou mais comentários no sentido de buscar no jornalismo uma forma de ajudar as pessoas atingidas, sensibilizando o leitor e as autoridades.

Os jornalistas percebem que o desastre não se resume ao evento catastrófico e a resposta consequente. E com esta percepção, têm a capacidade de promover a mitigação e preparação para desastres, recuperação a longo prazo e resiliência entre indivíduos, famílias e comunidades ${ }^{89}$, se conseguirem pensar na pauta do risco, além da cobertura do desastre. A reconstrução, a etapa seguinte à resposta, e a sensibilização da população, que amplia o interesse pelas etapas de prevenção e preparação, são consequências de uma boa cobertura. Mas ainda há uma dificuldade em lidar com esse papel, seja por desconhecimento dos profissionais sobre o que é 
risco e suas variadas formas de abordagem, por falta de treinamento, seja pela dificuldade em abordar pautas relacionadas a riscos e vulnerabilidades ${ }^{90}$ nas redações.

O protocolo de ação das Nações Unidas para a Redução de Riscos e Desastres (RRD), o Sendai Framework, firmado por 187 países em março de 2015, estabelece diretrizes de 2015 a 2030, com o foco de reduzir vulnerabilidades ${ }^{91}$ para ampliar a resiliência como forma de adaptação diante das mudanças climáticas.

Podemos ver neste foco, o papel do Jornalismo na prioridade número um, destacada no documento que prevê a necessidade da compreensão do risco de desastre em todas as suas dimensões de vulnerabilidades, capacidades, características das ameaças e do meio ambiente ${ }^{92}$. E ao ler o documento, fica evidente que essa é uma caminhada longa que envolve o enfrentamento e adaptação às mudanças climáticas e o desenvolvimento sustentável. O Sendai Framework une sob o guardachuva da RRD, metas relativas à biodiversidade, a erradicação da pobreza, meio ambiente, agricultura, saúde, alimentação e nutrição, entre outros ${ }^{93}$.

Em termos de pauta, estes são temas de impacto, relevantes e críticos que podem gerar matérias investigativas de denúncia e de grande interesse público. O jornalismo de qualidade é aquele que está sempre presente nas comunidades, ao lado da população, denunciando injustiças, crimes, desigualdades, escancarando as vulnerabilidades do nosso sistema social, cumprindo seus papeis percebidos e assumidos socialmente.

\footnotetext{
90 UNISDR. Sendai Framework for Disaster Risk Reduction 2015-2030. UN world conference on disaster risk reduction, 2015. (Sendai, Japan. Geneva: United Nations Office for Disaster Risk Reduction, March 14-18, 2015), p. 9.

91 Vulnerabilidades são "características e circunstâncias de uma comunidade ou sistema que os tornam suscetíveis aos efeitos daninhos de uma ameaça". Existem vários tipos de vulnerabilidade: socioeconômico, cultural, religioso, ambiental, físico, institucional, educacional, político, informacional e comunicacional, entre outros. A vulnerabilidade considera aspectos locais de uma comunidade como a capacidade de enfrentamento de situações adversas, que se traduz na combinação de todas as fortalezas, os atributos e recursos disponíveis dentro de una comunidade, sociedade ou organização. UNISDR. Terminologia de reducción de riesgo de desastres (Estrategia Internacional para la Reducción de Desastres de Las Naciones Unidas, 2009). p. 34 35.

92 UNISDR. Sendai Framework for Disaster Risk Reduction 2015-2030. UN world conference on disaster risk reduction, 2015. (Sendai, Japan. Geneva: United Nations Office for Disaster Risk Reduction, March 14-18, 2015).

93 UNISDR. Sendai Framework for Disaster Risk Reduction 2015-2030. UN world conference on disaster risk reduction, 2015. (Sendai, Japan. Geneva: United Nations Office for Disaster Risk Reduction, March 14-18, 2015), p. 9.
} 
Na cobertura de uma catástrofe ou emergência, o ângulo humano de um desastre tem $\mathrm{voz}^{94}$, já que nos relatórios técnicos as vítimas e atingidos são apenas números.

A mídia se torna mais que uma base de informações para o público, pois se espera que ela cumpra papeis que não são esperados durante a normalidade, como o de manter a comunidade unida em uma crise, em um mecanismo de defesa. Por consequência de uma cobertura bem feita, há a promoção do senso de comunidade e a solidariedade durante o desastre, como uma ligação entre as pessoas afetadas e o público que quer ajudar ${ }^{95}$.

\section{DIFICULDADES NA COBERTURA DE DESASTRES}

A primeira dificuldade que um jornalista enfrenta na cobertura é a logística necessária para entrar numa área de desastre e os problemas evidentes em um lugar destruído, como acessos bloqueados, desconhecimento do local, desabastecimento de víveres, água potável e combustível, queda de energia e de canais de comunicação, como internet e telefone ${ }^{96}{ }^{97}$. Ter que lidar com a quantidade enorme de informação obtida em campo no tempo necessário, se torna uma operação muito mais trabalhosa. Há também a dificuldade de acesso a informações corretas e a circulação de informações desencontradas, principalmente quando as fontes oficiais não estão preparadas para atender aos jornalistas ${ }^{98}$.

Ao analisar a história dos desastres observamos que, na maioria das vezes, as decisões para reduzir riscos são tomadas apenas depois da mobilização pública que um grande desastre provoca. Esse papel de mobilização pública é um dos mais importantes executados pela mídia. Mas, mesmo tendo ciência deste papel, há

\footnotetext{
${ }_{94}$ Camps, Periodismo sobre catástrofes, p. 31.

95 Marla Perez-Lugo, "Media uses in disaster situations: a new focus on the impact phase". Sociological Inquiry, Volume 74, Issue 2 , pages 210-225, (May 2004), p. 212.

96 Camps, Periodismo sobre catástrofes.

${ }_{97}$ Nieves-Pizarro, Takahashi and Chavez, "When".

98 Santos, "Do desastre para o risco".
} 
jornalistas que duvidam que a cobertura seja capaz de cumprir essas atribuições. A dimensão do desastre e o sofrimento humano, testemunhados durante a cobertura, podem transformar sua vida e provocar questionamentos sobre os valores do Jornalismo. Um dos entrevistados questiona sobre a capacidade e utilidade do Jornalismo em uma situação extrema:

Rodei com eles por duas noites. Aqueles repórteres eram o único resquício de civilização que restara entre tanta morte, destruição e violência. Eles não dormiam, não comiam e haviam perdido suas casas, amigos e parentes. Trabalhar era o que lhes restara. [...] A verdade é que os únicos jornalistas estritamente necessários naquela cobertura eram os da Rádio Concepción. (Igor Paulin, repórter)

A frase final levanta um questionamento do repórter sobre a utilidade da imprensa e é bastante comum a quem se depara com cenários devastadores, mesmo bombeiros, policiais, médicos, que, em algum momento, se sentem pequenos diante da tragédia humana.

Essa postura de descrença pode surgir diante do impacto emocional, ao testemunhar tamanho sofrimento e destruição. Há extensos estudos que exploram o transtorno de estresse pós-traumático (TEPT) entre socorristas e apenas alguns que abordam o trauma em meio aos jornalistas ${ }^{99}$. Algumas pesquisas abordam a saúde mental e psicológica de jornalistas em situações potencialmente traumáticas ${ }^{100} 101102$ ${ }^{103}$, enfocam a necessidade de preparo para esses momentos ${ }^{104}$ e abordam o trauma nas pautas cotidianas do jornalismo, não apenas em desastres ${ }^{105}{ }^{106}$. A relevância desses estudos mostra o humano que existe por detrás do jornalista ${ }^{107}$, e que eles

\footnotetext{
99 Tandoc Jr. and Takahashi, "Journalists".

100 Dworznik-Hoak, "Weathering the Storm".

101 Nieves-Pizarro, Takahashi and Chavez, "When".

102 Smith, Drevo and Newman, "Covering".

103 Edson C. Tandoc Jr. and Bruno Takahashi, "Journalists are humans, too: A phenomenology of covering the strongest storm on Earth"

${ }^{104}$ Hill, Luther and Slocum, "Preparing".

105 Smith, Drevo and Newman, "Covering".

106 Natalee Seely, "Fostering".

107 Tandoc Jr. and Takahashi, “Journalists”.
} 
costumam lidar com os mesmos tipos de estresse pós-traumático que as vítimas ${ }^{108}$. Os jornalistas entrevistados reconhecem essa dificuldade:

em Angra dos Reis, tive que entrevistar uma senhora que tinha perdido 11 parentes na tragédia. Não existem talento e treinamento suficientes para ocasiões como esta. (Rafael Pereira, repórter)

Somente quem esteve trabalhando em uma área de desastre pode tentar compreender o que sente um sobrevivente e o significado de "perder tudo". A dimensão dessas duas palavras não se resume ao "tudo" que pode ser mensurado, como casa e bens materiais, nem mesmo se somar os parentes e amigos que morreram. O "perder tudo" reflete a perda da própria identidade, do eixo que fazia a vida daquela pessoa ter sentido. Quando o jornalista se coloca no lugar de uma pessoa que viveu a vida toda em um bairro, com seus laços de amizade, parentes, trabalho, igreja, comunidade, vida familiar, escola e, de repente, tudo desaparece, ele pode começar a entender o significado de "perder tudo". Os repórteres entrevistados, revelam um certo constrangimento ao perceber sua situação em meio a esse cenário:

Nesse tipo de situação, em que o caos impera e pessoas duelam por um garfo recolhido entre escombros, não há como atuar sem certo embaraço e espanto. Embaraço, porque buscava contar a história de cadáveres e seus familiares sobreviventes sem qualquer intenção de ajudá-los diretamente. Mas agarravame à ideia de que meu serviço atrairia ajuda para as vítimas daquele descalabro. (Igor Paulin, repórter)

Sempre odiei abordar parentes de vítimas de tragédias recentes, com a dor ainda latente. Sabia que era meu dever, mas demorei para entender a real função de tanta invasão de privacidade. Com a experiência, descobri o quanto isso é fundamental. Se eu fizer um relato do que vejo, em terceira pessoa, o impacto das minhas palavras não será muito grande, por melhor que meu texto fique. Quando um parente de uma vítima dá seu depoimento, a nossa função é apenas a de relatar, porque o diálogo será direto entre esse parente em sofrimento e o leitor, no conforto de sua casa. Essa é a nossa função: Promover o diálogo entre os atingidos pela tragédia e o resto da população, que pode sair da inércia e fazer doações, cobrar as autoridades, votar melhor nas próximas eleições. (Rafael Pereira, repórter)

108 Budi Irawanto, "Narratives of natural disaster survivors in Indonesian media Pacific," Journalism Review, vol. 24 n. 1 (2018). 
Os entrevistados revelaram como lidavam com essa dificuldade:

Tenho por princípio não insistir com aquelas pessoas que não desejam falar. As que aceitam conceder entrevista, em geral, o fazem porque acham que expondo a própria situação estarão contribuindo para que algo semelhante não volte a acontecer. Há entrevistas também que funcionam como uma espécie de desabafo ou homenagem a quem se foi. Sempre tento mostrar para as pessoas que estou aberta a ouvi-las e que não tenho pressa. (Solange Azevedo, repórter)

Tinha um discurso pronto: "Prezado, gostaria muito de ter lhe conhecido e ter esta conversa contigo em outro momento de sua vida, anterior a este, em que você e sua família estivessem reunidos e felizes. Não é o caso. Gostaria de ouvi-lo e saber o que se passou aqui. Acredito que sua história, ao ser reverberada, atrairá a atenção do Brasil para enviar ajuda humanitária". Não há forma ideal, correta ou respeitosa o suficiente para lidar com quem perdeu tudo. Por mais diplomático e cauteloso que fosse, implicitamente estava ali uma pequena chantagem. O recurso retórico fez com que mais pessoas me recebessem apenas para contar suas histórias trágicas em troca de "um bem maior", a ajuda humanitária brasileira. Depois do terceiro cadáver, minha velocidade na apuração era muito maior. Entrava, convencia, ouvia e partia rapidamente. (Igor Paulin, repórter)

A verdade é que não existe fórmula, a abordagem vai depender da percepção e sensibilidade do jornalista ${ }^{109}$. Cada vez que aumentam sua experiência em coberturas de crises e desastres, os jornalistas ficam mais expostos a essa carga emocional, mas também têm os melhores conselhos e estratégias para lidar com eles, acabam desenvolvendo uma resiliência psicológica maior e também adquirem mais empatia ${ }^{110}$. A empatia pode contribuir para que os jornalistas tenham experiências positivas em associação com vítimas ou parentes, o que geralmente levam a mais segurança na cobertura de crises $^{111}$. Mas empatia aumenta a proximidade e até mesmo os mais experientes e resilientes se desgastam diante de tragédias humanas ${ }^{112}$.

Há sempre um desgaste emocional por parte de quem está lidando com uma tragédia. É terrível enfrentar a perda de vidas humanas numa escala tão intensa e manter a serenidade para fazer o melhor trabalho possível. (Celso Masson, editor executivo)

\footnotetext{
${ }^{109}$ Camps, Periodismo sobre catástrofes, p. 26.

110 Verhovnik, "Trauma".

111 Verhovnik, "Trauma".

112 Nieves-Pizarro, Takahashi and Chavez, "When".
} 
[...]considero que o mais delicado foi conduzir as entrevistas com as vítimas e familiares. Uma cobertura como essa é sempre muito difícil porque as pessoas envolvidas estão muito sensibilizadas e o repórter também se sensibiliza com o que vê e ouve. Tanto que, até hoje, se alguém me perguntar sobre esse caso me vem à cabeça um nome: Juliano. Ele é o rapaz que abre a reportagem e que perdeu a mulher e a filha, de 11 meses. Não consigo me esquecer do relato dele e do olhar vazio. Fiquei muito feliz ao vê-lo uns 2 anos depois dando uma entrevista para uma emissora de TV dizendo que havia se casado novamente e que teria mais um bebê. A sensação foi de que, apesar de tudo, ele estava tentando reconstruir a vida. (Solange Azevedo, repórter)

Nas entrevistas realizadas durante a pesquisa, os jornalistas foram perguntados sobre as dificuldades e o que consideram mais importante na cobertura. A resposta que mais se repetiu entre os repórteres, que atuaram em campo, foi a dificuldade em lidar com as pessoas afetadas e sobreviventes, devido à carga emocional e o constrangimento que isso envolve, mas também apontaram os relatos dessas pessoas como um dos aspectos mais significativos da cobertura. Os depoimentos dos sobreviventes enriquecem e humanizam a cobertura, mostram o impacto que aquilo causou na vida das pessoas. Um relato testemunhando o acontecimento, se bem escolhido e contextualizado pode sintetizar o que sucedeu a toda uma comunidade ${ }^{113}$.

Esse é um processo de retroalimentação, os atingidos precisam de informações, os não-atingidos querem saber o que aconteceu, inclusive para ajudar e os jornalistas têm seu principal papel para cumprir. Nesse processo, a mídia não está relatando emoções, mas também as gerando e educando as pessoas sobre elas e isso se torna um papel importante na política global de Redução de Riscos e Desastres ${ }^{114}$.

Desastres trazem uma enxurrada de emoções poderosas para a esfera pública e a mídia dedica boa parte da cobertura às emoções daqueles que sofreram ou foram afetados por desastres. São essas representações da mídia que permitem ao público se relacionar com os jornalistas que testemunham o choque, a dor, o medo e a raiva das vítimas de desastres. Essas expressões emocionais capturam a atenção do público e incentivam as pessoas a se envolverem e se solidarizarem ${ }^{115}$.

\footnotetext{
113 Camps, Periodismo sobre catástrofes, p. 192.

114 Irawanto, "Narratives".

115 Irawanto, "Narratives".
} 


\section{DESENVOLVENDO RESILIÊNCIA DIANTE DE DESASTRES E RESILIÊNCIA PSICOLÓGICA}

$\mathrm{Na}$ literatura sobre Redução de Riscos e Desastres se fala sobre o desenvolvimento da resiliência comunitária diante de desastres ${ }^{116}{ }^{117}$, mas nas pesquisas a resiliência psicológica também é muito abordada ${ }^{118}{ }^{119}$. Observamos que, quando tratamos de desastres, temos que trabalhar esses dois conceitos de resiliência. A resiliência diante de desastres é a capacidade de um sistema, comunidade ou sociedade expostos a uma ameaça para resistir, absorver, adaptar-se e recuperar-se de seus efeitos de maneira oportuna e eficaz, o que inclui a preservação e a restauração de suas estruturas e funções básicas ${ }^{120}$.

A resiliência psicológica é definida pela American Psychological Association como um processo de adaptação diante de adversidades, traumas, tragédias, ameaças e uma capacidade de lidar com a crise transformando-a em desenvolvimento pessoal $^{121}$. Ambas as definições se referem a fortalecer capacidades, sejam comunitárias, sejam individuais, e são relevantes para a abordagem de soluções relacionadas à Redução de Riscos e Desastres.

Os relatos que descrevem a dificuldade em aceitar que o jornalismo, assim como os bombeiros, os policiais, a defesa civil, a guarda nacional, o exército, os médicos, enfermeiros, psicólogos e demais equipes de atendimento ao desastre têm um papel limitado no desastre e o sentimento de impotência que isso gera, quando vistos do ponto de vista da psicologia, seriam melhores trabalhados no contexto do desenvolvimento da resiliência psicológica ${ }^{122}$.

\footnotetext{
116 Dworznik-Hoak, "Weathering the Storm".

117 Houston et al., "Disaster journalism".

118 Verhovnik, "Trauma".

119 Smith, Drevo and Newman, "Covering".

120 UNISDR, Terminologia de reducción de riesgo de desastres. (Estrategia Internacional para la Reducción de Desastres de Las Naciones Unidas, 2009), p. 28.

121 Verhovnik, "Trauma".

122 Smith, Drevo and Newman, "Covering".
} 
Percebemos que muito da frustração dos entrevistados e dos relatos provenientes da literatura são fruto do desconhecimento dos verdadeiros papeis do Jornalismo e do despreparo das redações e das escolas de Jornalismo em relação aos cuidados com os profissionais que vão a campo e são traumatizados ${ }^{123}{ }^{124}$. O sentimento de impotência é parte de um contexto que, mas trabalhado, leva ao Transtorno de Estresse Pós-Traumático, dentre outras patologias.

Muitas vezes, o que se espera da mídia é muito mais do que a mídia pode dar e os jornalistas acabam abraçando papeis para os quais não estão preparados, seja para amenizar um sentimento de culpa ou de inutilidade, pela proximidade que adquire com os afetados, pela empatia que aumenta no compartilhamento do sofrimento humano, ou pelo senso de dever, afinal, os limites do Jornalismo não ditam os limites pessoais de cada ser humano jornalista.

\section{CONCLUSÕES}

Este artigo trouxe uma análise qualitativa para fazer reflexões sobre os papeis executados pelos jornalistas em um desastre. Os papeis percebidos pelos entrevistados e os papeis revelados na literatura se revelaram consoantes com os fundamentos do jornalismo, apesar de terem aparecido papeis alternativos, que extrapolam o treinamento e o rol de atribuições básicas dos jornalistas.

As entrevistas foram realizadas em 2013, com jornalistas que tiveram a experiência de cobrir dois dos maiores desastres do Brasil, em 2008 e 2012 e outros desastres de grandes proporções que ocorreram até este ano. Uma das limitações das pesquisas sobre desastres é que se as entrevistas não são feitas imediatamente após os eventos, o conhecimento dos entrevistados se perde e as limitações se tornam mais severas, com resultados pouco realísticos. Isso mostra a importância de se preservar os dados originais de pesquisas realizadas, para posteriormente analisar sob

\footnotetext{
123 Hill, Luther and Slocum, "Preparing".

124 Smith, Drevo and Newman, "Covering".
} 
outros vieses. Partir do ponto de vista de jornalistas que atuaram em desastres trouxe uma dimensão prática da profissão, uma análise crua do campo, capaz de problematizar se os papeis que a Redução de Risco e Desastres e a sociedade em geral cobram do Jornalismo estão alinhados com os papeis percebidos pelos jornalistas.

Esta análise permite concluir que os fundamentos e parâmetros de qualidade convergem com uma cobertura de qualidade: fornecer informação verdadeira e de qualidade; mobilizar a opinião pública; dar voz aos atingidos; colaborar para o retorno à normalidade; investigar; cobrar medidas; fiscalizar; e denunciar o descaso com o interesse público.

Este estudo fornece perspectivas que contribuem para que os profissionais da comunicação não fiquem desamparados diante de dificuldades que extrapolam suas capacidades e os colocam diante de dificuldades que podem causar dano a sua integridade física e emocional. Quanto mais abrangentes forem essas perspectivas, mais acolhidos eles serão, poderão fazer melhor seu trabalho, e terão menos consequências para sua saúde mental e psicológica.

Uma limitação desta pesquisa é que não foi abordada a cobertura sob a influência da internet. Uma abordagem sob este ponto de vista é, por si própria, uma nova pesquisa, dada a complexidade da influência dos meios digitais, o que desviaria o foco deste artigo. Uma pesquisa futura poderia abordar este viés.

Pesquisas futuras podem ser feitas para aprofundar a relação da historicidade individual, considerando a resiliência psicológica de cada profissional e para fornecer embasamento e sistematização ao treinamento psicológico de repórteres na cobertura de desastres. Também há uma ausência de pesquisas que contribuam para compreender os produtos jornalísticos enquanto registros históricos.

\section{AGRADECIMENTOS}


Agradecemos à Universidade Federal de Santa Catarina, ao Departamento de Pós-Graduação em Engenharia e Gestão do Conhecimento e à Capes, Coordenação de Aperfeiçoamento de Pessoal de Nível Superior, fundação vinculada ao Ministério da Educação, por fornecer a bolsa de doutorado de dedicação exclusiva para Juliana Frandalozo Alves dos Santos.

\section{REFERÊNCIAS}

Banco de Dados S2ID. Banco de Dados de Registros de Desastres. Ministério da Integração Nacional. Secretaria Nacional de Defesa Civil. Universidade Federal de Santa Catarina. Centro Universitário de Estudos e Pesquisas sobre Desastres. "Sistema Integrado de Informações sobre Desastres." http://s2id.integracao.gov.br/. Acesso em 19 de maio de 2020.

Brasil. Ministério da Integração Nacional. Secretaria Nacional de Defesa Civil. Centro Nacional de Gerenciamento de Riscos e Desastres. "Anuário brasileiro de desastres naturais: 2012" (Centro Nacional de Gerenciamento de Riscos e Desastres. - Brasília: CENAD, 2012). 84 p. https://www.mdr.gov.br/images/stories/ArquivosDefesaCivil/ArquivosPDF/public acoes/AnuariodeDesastresNaturais_2013.pdf. Acesso em 17 de maio de 2020.

Campbell, Joseph. Getting It Wrong: Ten of the Greatest Misreported Stories in American Journalism. Berkeley, CA, Estados Unidos: University of California Press, 2010.

Camps, Sibila. Periodismo sobre catástrofes: cómo cubrir catástrofes, emergencias y accidentes en medios de transporte. Buenos Aires: Paulinas, 1999.

Castro, Antônio Luiz Coimbra. Manual de Planejamento em Defesa Civil - 4 volumes. Brasília: Ministério da Integração Nacional. Secretaria de Defesa Civil, 1999. http://gabinetemilitar.mg.gov.br/images/documentos/Defesa\%20Civil/manuais/M anual-PLANEJAMENTO-4.pdf. Acesso em 22 de abril de 2020.

Comfort, Suzannah Evans. "From ignored to banner story: The role of natural disasters in influencing the newsworthiness of climate change in the Philippines." Journalism (2019), Vol. 20(12) 1630- 1647, 201.

Denardi, Carol and Medeiros, Ricardo. CBN Diário: uma luz no apagão. Florianópolis: Insular, 2007. 
Dworznik-Hoak, Gretchen. "Weathering the Storm: Occupational Stress in Journalists Who Covered Hurricane Harvey." Journalism Studies, 21:1, 88-106, (2020). DOI: 10.1080/1461670X.2019.1628659

Ewart, Jacqui and McLean Hamish. "Best practice approaches for reporting disasters". Journalism (2019), Vol. 20(12) 1573-1592.

Friedman, Erin, Breitze, Rebekah and Solecki, William. "Communicating extreme event policy windows: Discourses on Hurricane Sandy and policy change in Boston and New York City." Environmental Science and Policy, 100 (2019) 55-65.

Guernsey, Lisa. "Hurricane Forces New Orleans Newspaper to Face a Daunting Set of Obstacles". The New York Times, September 5, 2005. http://www.nytimes.com/2005/09/05/business/media/05picayune.html?pagewa nted=all\&_r=0. Acesso em 14 de maio de 2020 .

Grassau, D., Puente, S., Vatter, N. and Rojas, R. "Perfiles y roles de los conductores de TV en momentos de desastres: propuesta conceptual a partir del caso del terremoto del 27F en Chile." Revista de Comunicación (2019), vol.18, n. 2. DOI: https://doi.org/10.26441/RC18.2-2019-A8

Hill, Desiree, Luther, Catherine A. and Slocum, Phyllis. "Preparing Future Journalists for Trauma on the Job". Journalism E Mass Communication Educator (2020), Vol. 75(1) 64-68. DOI: https://doi.org/10.1177/1077695819900735

Houston, J. Brian, Schraedley, Megan K., Worley, Mary E., Reed, Katherine and Saidi, Janet. "Disaster journalism: fostering citizen and community disaster mitigation, preparedness, response, recovery, and resilience across the disaster cycle." Disasters, Volume 43, Issue3 (July, 2019) Pages 591-611. DOI: 10.1111/disa.12352

Hua, Jinling and Shaw, Rajib. "Corona Virus (COVID-19) "Infodemic" and Emerging Issues through a Data Lens: The Case of China." Int. J. Environ. Res. Public Health (2020), 17, 2309 DOI: 10.3390/ijerph17072309

Irawanto, Budi. "Narratives of natural disaster survivors in Indonesian media Pacific." Journalism Review, vol. 24 No. 1 (2018): Disasters, cyclones and communication. DOI: https://doi.org/10.24135/pjr.v24i1.410

IFRC. International Federation of Red Cross and Red Crescent Societies. World Disasters 2005. Report Geneve: 2005. https://www.ifrc.org/Global/Publications /disasters/WDR/69001-WDR2005english-LR.pdf. Acesso em 12 de maio de 2020.

Karam, Francisco José Castilhos. A ética jornalística e o interesse público. São Paulo: Summus, 2004.

Keats, Patrice A. and Buchanan, Marla J. "Covering Trauma in Canadian Journalism: Exploring the Challenges." Traumatology 19(3) 210- 222, (2012). DOI: 10.1177/1534765612466152 
La, Viet-Phuong, Pham,Thanh-Hang, Ho, Manh-Toan, Nguyen, Minh-Hoang, Nguyen, Khanh-Linh P., Vuong, Thu-Trang, Nguyen, Hong-Kong T. et al. "Policy Response, Social Media and Science Journalism for the Sustainability of the Public Health System Amid the COVID-19 Outbreak: The Vietnam Lessons" Sustainability 2020, 12, 2931. DOI:10.3390/su12072931

McLean Hamish and Power Mary R. "When minutes count: Tension and trust in the relationship between emergency managers and the media." Journalism, Vol. 15(3) 307325 (2013). DOI: 10.1177/1464884913480873

Nieves-Pizarro,Yadira, Takahashi, Bruno and Chavez Manuel. "When Everything Else Fails: Radio Journalism During Hurricane Maria in Puerto Rico." Journalism Practice (2019), Vol. 13, n. 7, 799-816. DOI: https://doi.org/10.1080/17512786.2019.1567272

Perez-Lugo, Marla. Media uses in disaster situations: a new focus on the impact phase. Sociological Inquiry, Volume 74, Issue 2, pages 210-225, May 2004. DOI: https://doi.org/10.1111/j.1475-682X.2004.00087.x

Potter, Deborah and Ricchiardi, Sherry. Disaster and Crisis Coverage. International Center for Journalists, 2009. http://www.newssafety.org/images/stories/pdf/safetyresource/guides/ICFJ_disa ster_ENG.pdf. Acesso em 16 de maio de 2020.

Pulido, Cristina M, Villarejo-Carballido, Beatriz, Redondo-Sama, Gisela and Gómez, Aitor. "COVID-19 infodemic: More retweets for science-based information on coronavirus than for false information." International Sociology (2020), 1-16.

Rede Globo de Televisão. Jornal Hoje. "Moradores correm pelas ruas com medo de nova inundação." Nova Friburgo, RJ. Veiculado em 14 jan. 2011.

Rede Record de Televisão. Jornal da Record. "Boato de rompimento de represa gera pânico e tensão a Nova Friburgo." Nova Friburgo, RJ. Veiculado em 14 jan. 2011.

Santos, Juliana F. A. "Do desastre para o risco: qualidade na cobertura em revistas semanais de informação." Mestrado, Universidade Federal de Santa Catarina, 2014. https://repositorio.ufsc.br/handle/123456789/128973. Acesso em: 26 abr. 2020.

Seely, Natalee. "Fostering Trauma Literacy: From the Classroom to the Newsroom". Journalism \& Mass Communication Educator, Vol 75, Issue 1, 2020. DOI: https://doi.org/10.1177/1077695819859966

Smith, River J., Drevo, Susan and Newman, Elana. "Covering traumatic news stories: Factors associated with posttraumatic stress disorder among journalists." Stress and Health (2017); 1-9. DOI: 10.1002/smi.2775

Tandoc Jr., Edson C. and Takahashi, Bruno. "Journalists are humans, too: A phenomenology of covering the strongest storm on Earth". Journalism 1- 7, 2016. DOI: $10.1177 / 1464884916657518$ 
Tierney, Kathleen, Bevc, Christine and Kuligowski, Erica. "Metaphors matter: disaster myths, media frames, and their consequences in hurricane Katrina". The ANNALS of the American Academy of Political and Social Science. vol. 604 n. 1. Mar. 2006. DOI: https://doi.org/10.1177/0002716205285589

UNISDR. "Terminologia de reducción de riesgo de desastres". Estrategia Internacional para la Reducción de Desastres de Las Naciones Unidas, 2009.

UNISDR. "Sendai Framework for Disaster Risk Reduction 2015-2030". UN world conference on disaster risk reduction, 2015. Sendai, Japan. Geneva: United Nations Office for Disaster Risk Reduction, March 14-18, 2015.

Verhovnik, Melanie. “Trauma journalism and disaster resilience. German journalists' coping strategies when reporting about crime, violence, accidents, crises and natural disasters." Studies in Communication Sciences 17.2 (2017), pp. 209-220. DOI: https://doi.org/10.24434

\section{ANEXO}

\begin{tabular}{|c|c|}
\hline Papeis percebidos & Papeis atribuídos e alternativos \\
\hline $\begin{array}{l}\text { Informar, reportar a tragédia, divulgar, relatar, } \\
\text { fornecer informações verídicas e verificáveis }\end{array}$ & $\begin{array}{l}\text { Funcionar como um mecanismo de defesa, mantendo a } \\
\text { comunidade unida em uma crise }\end{array}$ \\
\hline $\begin{array}{l}\text { Organizar a informação em meio ao caos de boatos e } \\
\text { inverdades }\end{array}$ & $\begin{array}{l}\text { Fornecer diretamente suprimentos e outras assistências } \\
\text { à população } \\
7879\end{array}$ \\
\hline $\begin{array}{l}\text { Ouvir especialistas e técnicos, trazer explicações } \\
\text { claras e objetivas }\end{array}$ & $\begin{array}{l}\text { Tranquilizar a população, na ausência do poder } \\
\text { público } 80\end{array}$ \\
\hline Levantar discussões, conscientizar & Fazer o registro histórico do evento ${ }^{81}$ \\
\hline $\begin{array}{l}\text { Promover o diálogo entre os atingidos e os não- } \\
\text { atingidos. Cultivar a proximidade com a população }\end{array}$ & $\begin{array}{l}\text { Mobilizar ajuda para áreas isoladas e reconectar } \\
\text { famílias que se perderam } \\
82\end{array}$ \\
\hline Ampliar a cobertura de questões ambientais & Socorrista ${ }^{8384}$ \\
\hline $\begin{array}{l}\text { Fiscalizar, denunciar o descaso, irregularidades, como } \\
\text { o mau emprego do dinheiro público }\end{array}$ & \multirow{4}{*}{$\begin{array}{l}\text { Desenvolver conteúdo que promova a mitigação e } \\
\text { preparação para desastres, recuperação a longo prazo e } \\
\text { resiliência entre indivíduos, familias e comunidades }{ }^{85}\end{array}$} \\
\hline Educar & \\
\hline Cobrar e vigiar autoridades e o poder público & \\
\hline $\begin{array}{l}\text { Antecipar as tendências e os riscos, prevenir, criar } \\
\text { conhecimento para evitar novas vítimas }\end{array}$ & \\
\hline
\end{tabular}




\begin{tabular}{|c|c|}
\hline Papeis percebidos & Papeis atribuidos e alternativos \\
\hline $\begin{array}{l}\text { Informar, reportar a tragédia, divulgar, relatar, } \\
\text { fornecer informações verídicas e verificáveis }\end{array}$ & $\begin{array}{l}\text { Funcionar como um mecanismo de defesa, mantendo a } \\
\text { comunidade unida em uma crise }{ }^{77}\end{array}$ \\
\hline $\begin{array}{l}\text { Organizar a informação em meio ao caos de boatos e } \\
\text { inverdades }\end{array}$ & $\begin{array}{l}\text { Fornecer diretamente suprimentos e outras assistências } \\
\text { à população }\end{array}$ \\
\hline $\begin{array}{l}\text { Ouvir especialistas e técnicos, trazer explicações } \\
\text { claras e objetivas }\end{array}$ & $\begin{array}{l}\text { Tranquilizar a população, na ausência do poder } \\
\text { público }^{80}\end{array}$ \\
\hline Levantar discussões, conscientizar & Fazer o registro histórico do evento 81 \\
\hline $\begin{array}{l}\text { Promover o diálogo entre os atingidos e os não- } \\
\text { atingidos. Cultivar a proximidade com a população }\end{array}$ & $\begin{array}{l}\text { Mobilizar ajuda para áreas isoladas e reconectar } \\
\text { famílias que se perderam }^{82}\end{array}$ \\
\hline Ampliar a cobertura de questões ambientais & Socorrista $^{8384}$ \\
\hline $\begin{array}{l}\text { Fiscalizar, denunciar o descaso, irregularidades, como } \\
\text { o mau emprego do dinheiro público }\end{array}$ & \multirow{4}{*}{$\begin{array}{l}\text { Desenvolver conteúdo que promova a mitigação e } \\
\text { preparação para desastres, recuperação a longo prazo e } \\
\text { resiliência entre indivíduos, famílias e comunidades }\end{array}$} \\
\hline Educar & \\
\hline Cobrar e vigiar autoridades e o poder público & \\
\hline $\begin{array}{l}\text { Antecipar as tendências e os riscos, prevenir, criar } \\
\text { conhecimento para evitar novas vítimas }\end{array}$ & \\
\hline
\end{tabular}

\section{Los papeles del periodismo em los desastres: un análisis basado em la} experiência de los periodistas

\section{RESUMEN}

El periodismo desempeña papeles importantes en la gestión de riesgos y desastres, pero no sabemos mucho sobre sus límites, las dificultades para ejercerlo, cuál es una función reconocida y cuál es una función esperada, pero no forma parte de las funciones periodísticas. Este artículo tiene como objetivo comprender el papel del periodismo en los desastres, a partir del análisis de contenido de 13 entrevistas semiestructuradas cualitativas con periodistas brasileños con experiencia en cobertura de desastres, y de la revisión literaria. Los resultados muestran que los roles atribuidos al periodismo que están directamente relacionados con los fundamentos de la profesión no cambian, pero surgen otros roles o ganan más énfasis en los desastres. Los periodistas en el campo realizan algunos roles alternativos, incluso sin preparación emocional o entrenamiento específico para eso. Este estudio proporciona una perspectiva reflexiva sobre las dificultades que enfrentan los periodistas durante la cobertura de desastres, relacionados con roles autopercibidos, reconocidos y alternativos, y busca reforzar la necesidad de comprender la dimensión psicológica en el trabajo en eventos extremos.

Palabras-clave: periodismo; desastre; cobertura periodística; gestión de riesgos y desastres; fundamentos del periodismo. 